\title{
慢性関節リウマチ患者に対する
}

\section{顆粒球体外吸着療法 $(\mathrm{G}-1)$}

\author{
粕川禮司 ${ }^{* 1)}$, 吉野槇一 ${ }^{* 2)}$, 大原守弘 ${ }^{* 1)}$, \\ 藤森十郎 ${ }^{* 2)}$, 岡野 昭*3), 清水美津夫*3), \\ 江澤英光 $^{* 4)}$, 江澤和彦 ${ }^{* 4)}$, 阿岸鉄三*5)
}

\section{drug evaluation " vath}

Extracorporeal granulocyte adsorption treatment of patients with rheumatoid arthritis using a cellulose acetate beads $(G-1$ column)

A treatment involving the removal of granulocytes from the peripheral blood was attempted in patients with rheumatoid arthritis(RA) using a newly developed extracorporeal adsorbing column containing cellulose acetate beads $\left(\mathrm{G}^{-}-1\right.$ column, Japan Immunoresearch Laboratories, Takasaki).

A total of 63 patients with RA, from 4 hospitals, was treated from 2 to 10 times (a mean of 6.9 times) over a duration of 1 to 5 weeks (usually for 4 weeks) using the $\mathrm{G}^{-1}$ column. The $\mathrm{G}^{-1}$ column could remove up to $65 \%$ of granulocytes, based on comparison between blood entering and leaving the column.

For evaluating the therapeutic efficacy of the $\mathrm{G}^{-1}$ column, 59 patients were studied. The mean number of granulocytes in the peripheral blood decreased from $6754 \pm 358$ before to $5913 \pm 293 / \mu 1$ after $\mathrm{G}^{-1}$ column therapy, a $12.5 \%$ reduction. The Lansbury index which measures 4 parameters, swollen and tender joints, morning stiffness, grip strength and erythrocyte sedimentation rate, showed an improvement from $60 \%$ to $48 \%$ in the 59 patients evaluated. In a subset of 40 patients who received therapy for 4 weeks, the Lansbury index decreased from $60 \%$ to $54 \%$ at 1 week ( $<<0.001$ ), to $51 \%$ at 2 weeks $(\mathrm{p}<0.001)$, to $51 \%$ at week $3(\mathrm{p}<0.01)$ and to $48 \%$ at week $4(\mathrm{p}<0.001)$. The most prominent improvements were in tender joint scores from $79 \pm 5.6$ to $36 \pm 5.0(\mathrm{p}<$ $0.001)$ and grip strength from $120 \pm 9.6$ to $137 \pm 9.8 \mathrm{mmHg}(\mathrm{p}<0.001)$. No clinically significant side effects were observed in the 59 patients.

In conclusion, patients with RA showed an overall improvement of $61.0 \%$ and the usefulness of the $\mathrm{G}^{-1}$ column was judged to be $61.0 \%$.

Reiii Kasukawa*1), Shinichi Yoshino*2), Morihiro Ohara*1), Juhro Fujimori*2), Akira Okano*3), Mitsuo Shimizu*3),

Hidemitsu Ezawa*4), Kazuhiko Ezawa*4), Tetsuzo Agishi*5)

key words : apheresis, rheumatoid arthritis, granulocytes,

Lansbury index, cellulose acetate beads

炎症組織に集積してくる好中球等の顆粒球は, 貪食，活性酸素産生，顆粒内酵素の放出および組 織への遊走，接着など多彩な機能を有する細胞集 団であり，侵入微生物に対する生体防御に与る.

*1) Department of Internal Medicine II, Fukushima Medical College 福島県立医科大学第二内科学教室

*2) Department of Joint Disease, The First Hospital, Nippon Medical School 日本医科大学第一病院りウマ 千科

*3) Seneikai-Showa Hospital 千栄会昭和病院

*4) Kurashiki Kosai Hospital 倉敷廣済病院

*5) Kidney Center, Tokyo Women's Medical College 東 京女子医科大学腎臟病総合医療センター外科
一方，顆粒球が組織障害を引き起こすことも知ら れ, 心筋梗塞等での虚血後の再灌流障害 ${ }^{1)}$, 敗血症 等で誘発されるARDS (adult respiratory distress syndrome $)^{2)}$ おうび多藏器不全 ${ }^{3)}$, さらに慢 性関節リウマチ $(\mathrm{RA})^{4,5)}$ や系球体腎炎6)での組織 障害への関与が知られている。

慢性関節りウマチ $(\mathrm{RA})$ は, 多発性関節痛およ び骨破壊を伴う原因不明の全身性の慢性炎症であ り，その背景に液性および細胞性のさまざまな免 疫異常があることが知られている. 
表 1 試験施設・研究者一覧表

\begin{tabular}{|c|c|c|c|}
\hline 施設名 & 科名 & 研究者名 & 所在地 \\
\hline $\begin{array}{l}\text { 東京女子医科大学腎臓病 } \\
\text { 総合医療センタ- }\end{array}$ & 外科 & (O)阿岸鉄三 & 新宿区河田町 8-1 \\
\hline \multicolumn{4}{|l|}{ Aグループ } \\
\hline $\begin{array}{l}\text { 福島県立医科大学 } \\
\text { 倉敷廣済病院 } \\
\text { Bグループ }\end{array}$ & $\begin{array}{c}\text { 第二内科 } \\
\text { 内科 }\end{array}$ & $\begin{array}{r}\text { ○粕川禮司・大原守弘 } \\
\text { 江澤英光 } \cdot \text { 江澤和彦 }\end{array}$ & $\begin{array}{l}\text { 福島市光が丘 } 1 \text { 番地 } \\
\text { 倉敷市東塚 5-4-16 }\end{array}$ \\
\hline $\begin{array}{l}\text { 日本医科大学第一病院 } \\
\text { 昭和病院 }\end{array}$ & $\begin{array}{l}\text { リウマチ科 } \\
\text { 外科 }\end{array}$ & $\begin{array}{l}\text { ○吉野槙一・藤森十郎 } \\
\text { 岡野 昭 } \cdot \text { 清水美津夫 }\end{array}$ & $\begin{array}{l}\text { 千代田区飯田橋 3-5-5 } \\
\text { 高崎市綿貫町 } 1341\end{array}$ \\
\hline
\end{tabular}

○：代表世話人。 $\bigcirc$ :世話人

$\mathrm{RA}$ 患者の関節液，関節軟骨，パンヌスー関節 軟骨結合部7)や半月板組織8)には顆粒球の浸潤が 認められる。

関節液内には顆粒球遊走因子として作用する免 疫複合体が存在し ${ }^{9}$, , 関節軟骨表層部への免疫複 合体の沈着や複合体を貪食した顆粒球からのエラ スターゼの放出などが報告されている ${ }^{10)}$.また, RA 関節軟骨の抽出液にはタイプII コラーゲンに 対する自己抗体があり ${ }^{11)}$, Hugo ら ${ }^{12)}$ は, 顆粒球工 ラスターゼに暴露された軟骨はタイプII コラーゲ ン抗体を結合して, 関節破壊に関わるとしている.

顆粒球は炎症組織におけるエフェクタ一細胞と してばかりでなく，顆粒球自身が IL-1, IL-6, IL8 および $\mathrm{TNF}-\alpha$ を産生 ${ }^{13 \sim 15)}$ して，免疫調節にも 作用すると理解されている. IL-8 は顆粒球の遊走 因子であるとともに，顆粒球の活性化や脱顆粒を 促し，顆粒球による軟骨破壊を増強すると報告さ れている ${ }^{16)}$.

このような背景のもと, RA 患者の治療の一環 として末梢血顆粒球を体外吸着する顆粒球体外吸 着器・G-1 が考案された。そこで今回, G-1 療法 の有効性, 安全性, 有用性および用法・用量を確 認するため臨床試験を実施した．

\section{対象と方法}

\section{実施施設}

本試験は東京女子医科大学腎臓病総合医療セン ター外科阿岸鉄三教授を代表世話人として，4 施 設で実施された(表 1 )。

\section{対象症例}

対象は，アメリカリウマチ協会 (ARA, 1987年) の診断基準により慢性関節りウマチ $(\mathrm{RA})$ と診断 され, 発证後 6 力月以上経過し, 試験開始時に下 記 5 項目中 3 項目を満たす症例とした。

(1) 握力 (左右の平均值) - 男 : $161 \mathrm{mmHg}$ 以 下，女：127 mmHg 以下

(2) 赤沈値 (Westergren 法)：21 mm 以上/1 時間

(3) 疼痛(運動痛または圧痛)の認められる関節 数：6 関節以上

(4) 腫脹の認められる関節数： 3 関節以上

(5) 朝のこわばりの持続時間：30 分以上

なお，対象は性別を問わないが，下記の患者は 対象から除外することとした。

(1) 17 歳以下, 76 歳以上の患者

(2) 妊娠中，授乳中の女性，妊娠している可能 性のある女性，および本試験期間中に妊娠を希望 する女性

(3) 心疾患, 腎疾患, 肝疾患, 血液疾患その他 重篤な合併症もしくは，その既往歴を有する患者

(4) 免疫抑制剂 (CY, AZ, MTX 等)，免疫調節 剂(レバミゾール，CCA 等)，金製剂， D-ペニシラ ミン等の抗りウマチ剤が治療開始後 3 力月以内の 患者または維持療法に達していない患者

(5) 最近 1 力月以内にステロイド剤投与を開始 した患者，また，試験期間中にステロイド剤の関 節注入を必要と思われる患者，または 2 週間以内 に関節注入を受けた患者

（6)最近手術を受けたもので，手術侵襲の影響 が考えられる患者

(7) その他，医師が試験対象として不適当と判 
表 2 試験スケジュールおよび検査・評価項目

\begin{tabular}{|c|c|c|c|c|c|c|}
\hline \multirow{2}{*}{\multicolumn{4}{|c|}{ 時期 }} & 予備観察期間 & 治療観察期間 & 経過観察期間 \\
\hline & & & & $-2 \sim 0$ 週 & $1 \sim 8$ 週 & $1 \sim 4$ 週 \\
\hline \multicolumn{4}{|c|}{ 顆粒球体外吸着療法 (G-1 療法) } & \multicolumn{3}{|c|}{$1 \sim 3$ 回/週の治療を $1 \sim 8$ 週施行 } \\
\hline \multicolumn{4}{|c|}{ 基礎治療 } & \multicolumn{3}{|c|}{ 試験期間は同一条件で行う。 } \\
\hline \multirow{7}{*}{$\begin{array}{l}\text { 検 } \\
\text { 查 } \\
\text { お } \\
\text { よ } \\
\text { び } \\
\text { 評 } \\
\text { 価 }\end{array}$} & \multirow{4}{*}{$\begin{array}{l}\text { 有 } \\
\text { 効 } \\
\text { 性 } \\
\text { 評 } \\
\text { 価 }\end{array}$} & $\begin{array}{l}\text { 背景 } \\
\text { 調查 }\end{array}$ & Stage, Class(ARA による) & $\bigcirc$ & & \\
\hline & & \multirow[t]{2}{*}{$\begin{array}{l}\text { 自他覚 } \\
\text { 的所見 }\end{array}$} & $\begin{array}{l}\text { 握力 }{ }^{* 1)}, \text { 赤沈值 }{ }^{* 2)} \text {, 活動性関節点数 }{ }^{* 3)} \text {, } \\
\text { 朝のこわぼり持続時間 } 4), \text { Lansbury 活 } \\
\text { 動性指数, 疼痛点数*4), ADL }{ }^{* 4)}\end{array}$ & O & 各週に 1 度検査する。 & $\bigcirc$ \\
\hline & & & 患者の評価*4), 医師の評価*5) & & O & 0 \\
\hline & & $\begin{array}{l}\text { 免疫学 } \\
\text { 的検查 }\end{array}$ & $\begin{array}{l}\mathrm{RF}(\operatorname{IgG}), \mathrm{RF}(\operatorname{IgM}), \mathrm{CRP}, \operatorname{IgG}, \operatorname{Ig} \mathrm{A} \\
\mathrm{IgM}, \mathrm{CD} 4 / 8\end{array}$ & O & 各週に 1 度検査する。 & O \\
\hline & \multirow{3}{*}{$\begin{array}{l}\text { 安 } \\
\text { 金 } \\
\text { 性 } \\
\text { 評 } \\
\text { 価 }\end{array}$} & 血液 & $\begin{array}{l}\mathrm{RBC}, \mathrm{Hgb}, \mathrm{Ht}, \mathrm{WBC}, \mathrm{WBC} \text { 分画, } \\
\mathrm{PLT}, \mathrm{PT} \text { (時間), フィブリノーダン }\end{array}$ & $\bigcirc$ & 各週に 1 度検査する。 & O \\
\hline & & $\begin{array}{l}\text { 血液 } \\
\text { 生化学 }\end{array}$ & $\begin{array}{l}\text { GOT, GPT, } \gamma \text {-GTP, Alp, LDH, T. B, } \\
\mathrm{Alb}, \mathrm{A} / \mathrm{G} \text { 比, BUN, Cr, HA, Na, K, } \\
\mathrm{Cl}, \mathrm{Ca}\end{array}$ & O & $\begin{array}{l}\text { 治㙩終了後に実施または } \\
4 \text { 週に1度奏施する. }\end{array}$ & O \\
\hline & & 尿 & 蛋白, 糖, ウロビリノーゲン, 潜血 & $\bigcirc$ & $\begin{array}{l}\text { 治療終了後に実施または } \\
4 \text { 週に } 1 \text { 度実施する。 }\end{array}$ & $\mathrm{O}$ \\
\hline \multicolumn{4}{|c|}{ 副作用 } & & $\bigcirc$ & $\mathrm{O}$ \\
\hline \multicolumn{4}{|c|}{ 総合評価(最終全般改善度，概活安全度，有用度） } & & & O \\
\hline
\end{tabular}

*1) 水銀圧力計, 初圧 $20 \mathrm{mmHg}$ にて, 左右各 3 回測定值の最高値の平均

*2) Westergren 法で 1 時間値

*3) 疼痛関節数㧍よび腫脹関節数

*4)「私のリウマチ日記」より記載

*5) 治療開始前に比し, 著明改善, 改善, やや改善, 不変, やや悪化, 悪化, 著明悪化の 7 段階で評価

断した患者

\section{被験者に対する説明と同意}

治験担当医師は試験実施に際し，試験の目的， 内容，期間，期待される効果および予測される副 作用を被験者に十分説明し，文章または口頭にて 本試験への参加の同意を得，その年月日を調査表 に記入した。

\section{試験方法}

\section{(1) 試験形式}

本試験の形式は，医療用具の性質上オープン形 式とした。また，薬剤との併用については，維持 療法に達している薬剤は，試験期間，観察期間と もに同一条件で行うこととした。試験スケジュー ルを表 2 に示した。

（2）試験用具の配付および体外循環装置とそ の方法
試験 G-1 および体外循環装置は，(株日本抗体研 究所が供与した。

G-1 は約 $220 \mathrm{~g}$ の酢酸セルロースビーズ(直 径：約 $2 \mathrm{~mm}$ )を吸着材としてカラムに充填し, 血 液ポンプ(泉工医科工業株式会社, $\mathrm{KBM}-1$ )に よって患者の血液を流す血液体外循環装置(人工 透析用の血液回路と駆動装置の組み合わせ)で, 血 液流量は $30 \mathrm{ml} / \mathrm{min}$ を，循環時間は 60 分を設定 值とし, 人工透析での操作と同様の注意点(回路の 入出口での圧力など)に留意しながら, 所定の操作 法に従って実施した(図 1 )。

循環前の処置としては，あらかじめ G-1 と循環 回路をへパリン加生理食塩液を用いて十分に脱気 および平衡化の処理をした。所定治療時間が終了 したら血液ポンプを停止し， G-1 と循環回路にあ る血液を患者に返血するために生理食塩液を流し た，抗凝固剤としてはへパリンを用い，投与の量 と方法は患者の状態に合わせて担当医が調整し 


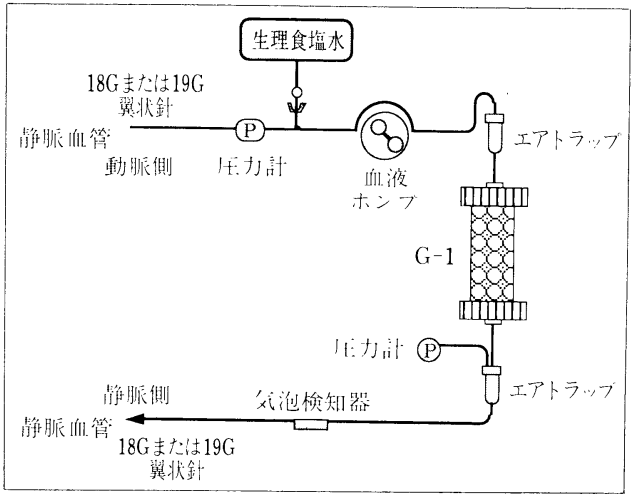

図 1 G-1, 一循環図一

た。ブラッドアクセスは，基本的には $18 \mathrm{G} \mathrm{0}$ の翼 状針を用いた静脈一静脈とし, 患者の状態に合わせ て担当医が決定した.

（3）用法用量および治療回数

(1) 1 回の治療には原則として 1 本の $\mathrm{G}^{-1}$ を 用いた。

(2) 1 回の治療における体外循環時間は原則と して 60 分とした。

(3) 治療回数は, 週 $1 \sim 3$ 回 ( 1 クール) とし, 患者の症状, 医師の判断により 1 週以上 8 週以内 とした.

(4) G-1 は 1 回限りの使い捨てとした.

(4) 併用療法

(1) 非ステロイド抗炎症剤および鎮痛剂の併用 を行う場合は，観察開始前および観察期間中を通 じて同一条件で併用した

(2) 維持療法に達している金製剤, D-ペニシラ ミン，ステロイド剤，免疫抑制剤(CY, AZ, MTX 等), および免疫調節剤 (レバミゾール, CCA 等) 等は，観察開始前および観察期間中を通して同一 条件で併用した。ただし，これらの薬剤と併用す る場合には，本治療前の臨床経過を調查表・患者 背景闌に記入することとした。

(3) その他, 本試験の効果と副作用に直接影響 を及ぼさないと考えられる薬剤の併用は，必要に 応じて行ってもよいこととした。

(4) 観察期間中の新規な理学療法は避け，観察 期間前から行っているものについては，観察開始 前および観察期間中を通して同一条件で併用し た。
(5) 観察期間中の関節穿孔および排液は原則と して行わない。やむをえず行った場合は，その旨 を調查表に記入することとした。

\section{臨床評価}

（1）患者調査

本試験開始前に下記の項目について背景調査を 行った.

患者名，性別，年歯，外来-入院，診断 (stage, class)，RA test, 罹病期間，合併症，既往歴，手 術歴，観察期間開始前 4 週間の既知療法，同意の 有無, 観察期間のリウマチ活動性(握力, 赤沈值, 活動性関節，朝のこわばり等)

（2）有効性観察項目

試験開始日および試験開始後 1 週間ごとに以下 の項目について表 2 に示したスケジュールで評価 した。また，試験開始 1 週間前より毎日，リウマ チ日記（朝のこわばり，疼痛点数，ADL）の記載を 行った。

(1) 握力：左右それぞれ 3 回ずつ測定し，それ ぞれの最高值を記入した。

(2) 赤沈值：Westergren 法による1時間値を 記録した。

(3) 活動性関節数：疼痛および腫脹のある関節 部位を記入し，関節点数に換算した。

(4) 朝のこわばりの持続時間

(5) Lansbury の活動性指数：上記, 握力, 赤沈 値，活動性関節数，朝のこわばりの持続時間の 4 項目の活動性指数の合計 (\%)

(6) 疼痛点数：評価日前 1 週間平均值 (リウマ チ日記より)

(7) $\operatorname{ADL}$ (日常生活動作)：評価日前 1 週間の 平均値(リウマチ日記より)

(8) 医師の所見：試験開始時との比較で，著明 改善, 改善, やや改善, 不変, やや悪化, 悪化, 著明悪化，の 7 段階で観察した。

(9) 患者の所見：試験開始時との比較で，前よ り非常に良い，前より良い，変わらない，前より 悪い，前より非常に悪い，の5段階で観察した。

(10)生化学検査: RF 定量, RF (IgG) 定性, CRP 定量，免疫グロブリン分画，CD4/8 比

（3）安全性観察項目

試験開始日および試験開始後 4 週間ごとに以下 
の項目について検査を行つた。また, 本試験にお ける副作用の症状, 程度, 発現時期, 処置, 経過 などを詳細に観察し，記録した。

(1) 血圧(最高血圧, 最低血圧), 脈拍, 体温

(2)一般血液検査(赤血球数, ヘモグロビン，へ マトクリット, 血小板数, 白血球数, 白血球分画), フィブリノーゲン，プロトロンビン時間

(3) 血液生化学検查 (GOT, GPT, $\gamma$-GTP, Al $\mathrm{p}, \mathrm{LDH}$, 総ビリルビン, 総蛋白, アルブミン, A/ $\mathrm{G}$ 比, BUN, クレアチニン, 電解質)

(4) 尿検查(蛋白, 糖, ウロビリノーゲン, 潜血) (4) 総合評価

総合評価として，G-1の最終全般改善度, 概括 安全度, 有用度について試験終了時に評価した。

(1) 最終全般改善度の評価：試験中の全過程を 試験開始時と比較して, 著明改善( 3 ), 改善 ( 2), やや改善 $(1)$, 不変 $(0)$, やや悪化 $(-1)$, 悪化 $(-2)$, 著明悪化 $(-3)$ の 7 段階で評価した。評 価基準は日本りウマチ財団薬効検定委員会が一般 的に採用している Lansbury の活動性指数の変化 を目安に行った。しかし, リウマチ日記や他の検 查值を鑑み、これと異なる評価をする場合は，そ の旨を明記することとした。

(2) 概括安全度の評価：試験中の副作用, 臨床 検查值を考慮して, 試験終了時に全般的な安全度 を, 安全である( 0 ：副作用なし), ほぼ安全であ る(-1：副作用はあったが治療継続可能), 安全 に問題がある $(-2$ : 副作用のため処置が必要), 安全でない $(-3$ : 副作用のため治療中止あるい は中止すべきであった)の 4 段階で評価した。

(3) 有用度の評価：試験終了時に最終全般改善 度, および概括安全度を総合的に判断し, きわめ て有用 ( 3 ), 有用 (2), やや有用 (1), どちらと もいえない( 0$)$, やや好ましくない $(-1)$, 好ま しくない(-2), きわめて好ましくない $(-3) 0$ 7 段階で評価した。安全度が 0 の場合は最終全般 改善度の評価に準拠し，これと相違する場合は， その旨を明記した。 また, 安全度がー $1,-2$ およ びー 3 の場合, その内容に応じて総合的に判断し, 有用度を決定した。但し，その旨を明記すること とした。

（5）中止例および処置

症状の悪化, 副作用の発現した例で試験の継続
が不適当と判断された場合は中止し，その時期お よび中止理由を調査表に明記し，可能な限り判定 することとした．

（6）症例の取り扱いおよび解析方法

判定委員会において, 各症例を吟味し, 問題症 例については，下記の基準に従って中止，脱落， 除外の取り扱いを決定した。

(1) 中止例：試験期間が 1 クール( 1 週間) に満 たない症例および試験期間，観察期間を含め，4 週未満の症例

(2) 脱落例：試験期間中に手術を施行した症例

(3) 除外例：他剂および他療法の前治療期間が 短く，本試験の薬効評価に影響を及ぼすと考えら れる症例，および観察期間中に維持療法に達して いる薬剤・治療を変更した症例, データの解析に おいて，患者背景因子の等質性の検定は $2 \times \mathrm{n}$ 分 割表による $\chi 2$-test を用いた。また，有効性評価 項目についてはStudent の paired t-test を用い た.

\section{試験成績}

\section{G-1 の吸着特性}

（1） G-1 に吸着される細胞・蛋白

顆粒球体外吸着療法を行った患者の中で, G-1 治療中に G-1 通過前および通過後より採血でき た 6 症例の白血球抢よび血清蛋白を通過前後で比 較することにより，G-1に吸着される白血球およ び血清蛋白の種類を検討した（表 3 )。 その結果, G-1 に吸着される白血球および血清蛋白は単球 を含む顆粒球が大部分で, 赤血球, リンパ球，血 小板, 総蛋白, アルブミン, IgG, IgA, IgM およ び RF は， G-1 通過前後で有意の差を認めなかっ た。

そこで，顆粒球体外吸着療法を行った患者の中 で治療直後に G-1 を回収した 7 症例について, G-1 に吸着する白血球中の顆粒球の割合を検討 した(表 4 )。その結果，G-1 に吸着した白血球の 95\%が単球を含む顆粒球であり，G-1 は顆粒球吸 着の特異性が高い医療用具であることが示され た。 
表 3 RA 患者での白血球, 沮清蛋白の G-1 吸着特性

\begin{tabular}{|c|c|c|c|c|}
\hline & & G-1 流入前 & G-1 流出後 & 検定 (p value) \\
\hline 赤血球数 & $\left(\times 10^{6} / \mathrm{mm}^{3}\right)$ & $3.61 \pm 0.22$ & $3.53 \pm 0.25$ & NS \\
\hline 血小板数 & $\left(\times 10^{3} / \mathrm{mm}^{3}\right)$ & $293 \pm 22$ & $311 \pm 19$ & NS \\
\hline リンパ球数 & $\left(\times 10^{3} / \mathrm{mm}^{3}\right)$ & $1.22 \pm 0.15$ & $1.20 \pm 0.14$ & NS \\
\hline 顆粒球数 & $\left(\times 10^{3} / \mathrm{mm}^{3}\right)$ & $6.87 \pm 1.44$ & $2.41 \pm 0.48$ & $\mathrm{p}<0.01$ \\
\hline 単球数 & $\left(\times 10^{3} / \mathrm{mm}^{3}\right)$ & $0.28 \pm 0.07$ & $0.12 \pm 0.03$ & $\mathrm{p}<0.01$ \\
\hline 総 蛋 白 & $(\mathrm{g} / \mathrm{dl})$ & $7.28 \pm 0.17$ & $7.30 \pm 0.18$ & NS \\
\hline アルブミン & $(\mathrm{g} / \mathrm{dl})$ & $3.63 \pm 0.12$ & $3.58 \pm 0.09$ & NS \\
\hline $\operatorname{IgG}$ & $(\mathrm{mg} / \mathrm{dl})$ & $2396 \pm 217$ & $2353 \pm 240$ & NS \\
\hline $\operatorname{Ig} A$ & $(\mathrm{mg} / \mathrm{dl})$ & $698 \pm 107$ & $683 \pm 115$ & NS \\
\hline $\operatorname{IgM}$ & $(\mathrm{mg} / \mathrm{dl})$ & $199 \pm 30$ & $191 \pm 28$ & NS \\
\hline RF & $(\mathrm{U} / \mathrm{ml})$ & $234 \pm 64$ & $230 \pm 61$ & NS \\
\hline
\end{tabular}

paired t-test. NS : not significant. I)ata, mean $\pm \mathrm{SE}$

表 4 RA 患者における（１１への吸着細胞特異性

\begin{tabular}{|c|c|c|c|c|c|c|}
\hline \multirow{2}{*}{ (症患者 } & \multirow[b]{2}{*}{ 年齢 } & \multirow[b]{2}{*}{ 性別 } & \multirow[b]{2}{*}{ stage } & \multirow[b]{2}{*}{ class } & \multicolumn{2}{|c|}{ G-1 に結合した白血球 } \\
\hline & & & & & $\begin{array}{c}\text { \%顆粒球 } \\
\text { (CD15 陽性細胞) }\end{array}$ & $\begin{array}{l}\text { \%マクロファージ } \\
\text { (CD14 陽性細胞) }\end{array}$ \\
\hline 006 & 48 & $\mathrm{~F}$ & IV & 2 & 90.9 & 4.0 \\
\hline 007 & 56 & $\mathrm{~F}$ & III & 2 & 95.2 & 3.8 \\
\hline 008 & 63 & $\mathrm{~F}$ & IV & 4 & 78.2 & 7.4 \\
\hline 011 & 58 & $\mathrm{~F}$ & IV & 3 & 88.9 & 6.8 \\
\hline 013 & 48 & $\mathrm{~F}$ & II & 2 & 88.4 & 5.1 \\
\hline 034 & 65 & $\mathrm{~F}$ & II & 2 & 89.6 & 5.0 \\
\hline 039 & 41 & M & I & 1 & 93.5 & 5.8 \\
\hline \multicolumn{5}{|c|}{ 平均 $($ mean $\pm \mathrm{SD})$} & $89.2 \pm 5.5$ & $5.4 \pm 1.3$ \\
\hline
\end{tabular}

7 例の RA 患者について，G-1 終了後(返血後) $37^{\circ} \mathrm{C}$ に加温した生食 $300 \mathrm{ml}$ で $\mathrm{G}^{-1}$ を 洗浄した後, $0.2 \%$ EDTA, $0.1 \%$ BSA を含む冷却 PBS $500 \mathrm{ml}$ で白血球を回収した. 白血球に抗顆粒球 (CD15) および抗マクロファージ (CD14) モノクローナル抗体を反応 させ,フローサイトメトリーでおのおの陽性細胞の比率を計測した。

\section{(2) 顆粒球吸着効率}

G-1 の顆粒球およびリンパ球に対する吸着能 を調べるために，全症例 63 例について G-1 の出 入口で未梢血の顆粒球とリンパ球の数を調べた (図 2 )。顆粒球については末梢血の顆粒球数が多 くなるほど $\mathrm{G}^{-1}$ への吸着数も多くなり，末梢血の 顆粒球数と G-1 へ吸着した顆粒球数との間に正 の相関が認められた $(\mathrm{p}=0.0001)$ 。一方，リンパ 球はほとんど吸着されず，末梢血リンパ球数と吸 着したリンパ球数との間には相関は認められな
かった。また，G-1 に吸着された細胞数は顆粒球 が, $4.91 \pm 0.26 \times 10^{9}$ 個, リンパ球が $0.12 \pm 0.03$ $\times 10^{9}$ 個であり, 吸着効率は顆粒球が $48.3 \pm$ 1.21(\%), リンパ球が $5.4 \pm 1.04$ (\%)であった(表 $5)$.

（3） G-1 治療中の末梢血顆粒球数の推移

G-1 治療を行った 63 例について, G-1 治療中 の顆粒球数の推移を $\mathrm{G}^{-}-1$ 通過前後の值を指標に 検討した。

図 3 に示したように, 測定できた各時点(15 分, 
表 5 G-1 への白血球吸着効率

\begin{tabular}{lcccrr}
\hline \multicolumn{1}{c}{ 細胞 } & 症例数 & $\begin{array}{c}\text { 末松血細胞数 } \\
\left(/ \mathrm{mm}^{3}\right)\end{array}$ & $\begin{array}{c}\mathrm{G}-1 \text { 吸着細胞数 } \\
\left(\times 10^{9} \text { 個 }\right)\end{array}$ & $\begin{array}{c}\mathrm{G}-1 \text { 通過細胞数 } \\
\left(\times 10^{9} \text { 個 }\right)\end{array}$ & $\begin{array}{c}\text { 吸着効率 } \\
(\%)\end{array}$ \\
\hline 顆粒球 & 63 & $6661 \pm 344.1$ & $4.91 \pm 0.26$ & $10.35 \pm 0.54$ & $48.3 \pm 1.21$ \\
リンパ球 & 63 & $1370 \pm 72.9$ & $0.12 \pm 0.03$ & $2.28 \pm 0.13$ & $5.4 \pm 1.04$ \\
\hline
\end{tabular}

mean $\pm \mathrm{SE}$
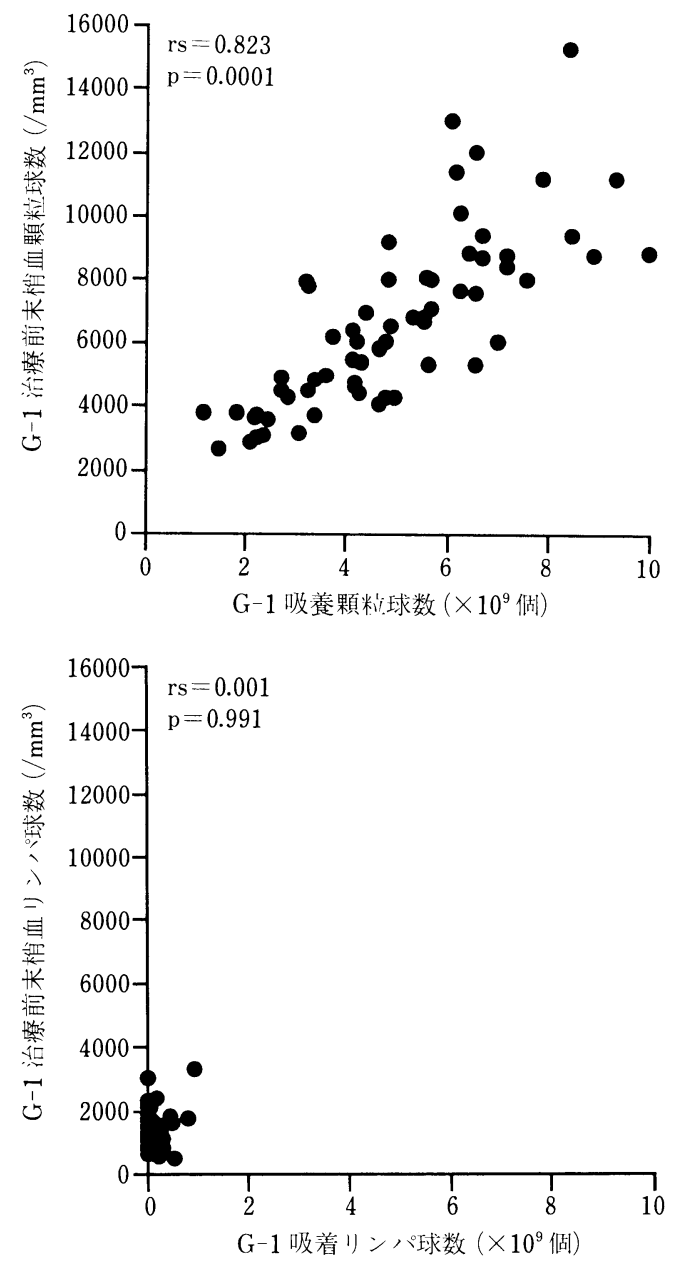

$\mathrm{rs}=$ Spearman's rank correlation coefficient, $\mathrm{n}=63$

図 2 G-1 療法による治療前末梢血白血球数と 吸着細胞数の相関関係

30 分, 60 分)において, 顆粒球は $\mathrm{G}-1$ 流入側 (In) に比し流出側 (Out)で有意に低下しており，60 分 間の治療において，G-1 が十分な顆粒球吸着性能 を有していることが示された。

しかし, 治療終了 $3 \sim 4$ 日で, 顆粒球数は治療 前值の $92 \%$ に戻った。
表 6 施設別症例数抢よび治療回数

\begin{tabular}{c|c|c|c}
\hline \multirow{2}{*}{ グループ } & 施設名 & \multirow{2}{*}{ 症例数 } & 治療回数 \\
\cline { 3 - 4 } & & & G-1 回数 \\
\hline \multirow{2}{*}{$\mathrm{A}$} & 福島医科大学 & 10 & 79 \\
\cline { 2 - 4 } & 倉敷廣済病院 & 26 & 156 \\
\cline { 2 - 4 } & 小計 & 36 & 235 \\
\hline \multirow{2}{*}{ B } & 日本医科大学第一病院 & 18 & 140 \\
\cline { 2 - 4 } & 昭和病院 & 9 & 62 \\
\cline { 2 - 4 } & 小計 & 27 & 202 \\
\hline \multirow{2}{*}{ 合計 } & 63 & 437 \\
\hline
\end{tabular}

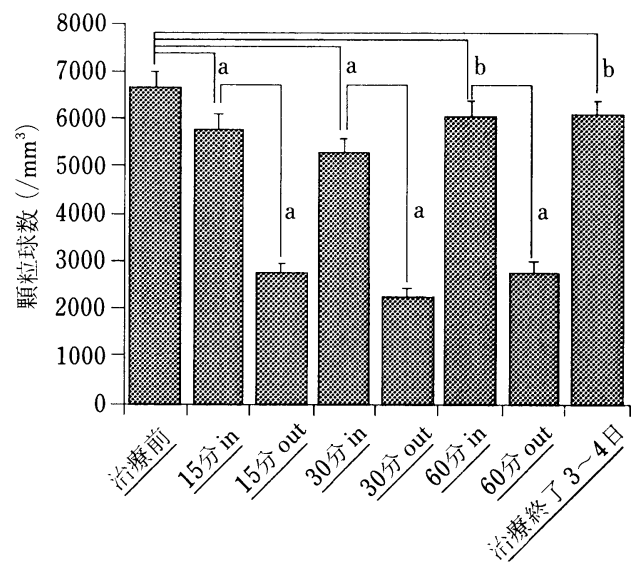

Paired t-test. a:p $<0.001$. b: $p<0.01$

図 $3 \quad \mathrm{G}-1$ 治療中の顆粒球数の推移

\section{症例の構成}

今回, 治療を実施した総症例は合計 63 例であっ た。総症例の内訳は, 安全性評価症例 63 例, 有効 性評価症例 59 例, 有効性評価除外症例 4 例であっ た(図 4 )。また，有効性評価除外症例 4 例は維持 療法に達している薬剤・治療の変更であった。

施設別症例数抢よび治療回数を表 6 に示した。

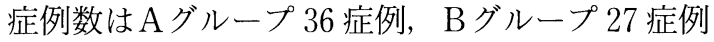
であり, 治療回数は Aグループ 235 回治療(平均 6.5 回), B グループ 202 回治療 (平均 7.5 回)であ 
表 7 グループ別症例背景一覧表

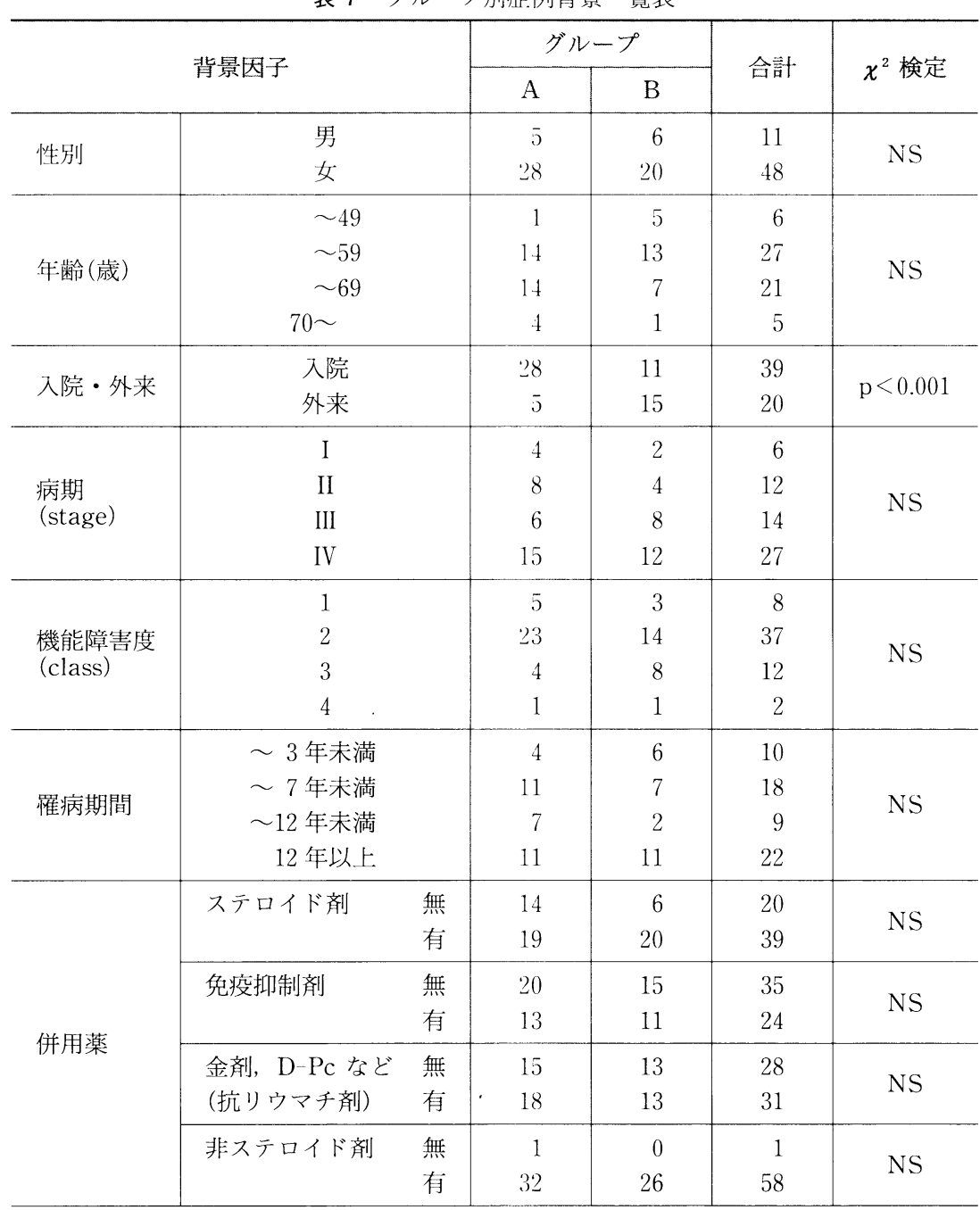

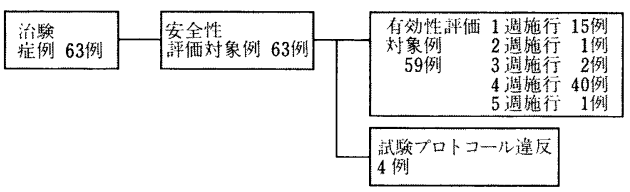

図 4 症例構成

り，グループ間での症例数および治療回数に有意 な差はなかった $\left(\chi^{2}\right.$ 検定 $)$

\section{症例の背景}

有効性評価症例 59 例のグループ別背景因子層別 結果を表 7 に示した，ステロイド剤が $66 \%$ ，免疫 抑制剤が $41 \%$ ，金剂，D-ペニシラミンなどの抗リ
ウマチ剂が53\%に使われこれら 3 㓮のいずれも が使われていない症例は 2 例のみであった。入院 患者がAグループに多かったことを除いて，グ ループ間の患者背景に有意な差は認められなかっ た。

また，疾患の性質上対象患者に女性が多かった が,グループ間での有意な差は認められなかった。

\section{有効性評価各項目の検討結果}

(1) Lansbury 指数の経時変化

Lansbury 指数は，G-1 治療終了後では前值に 比し $21.1 \%(60.2 \% \rightarrow 47.5 \%)$ 改善した $(\mathrm{p}<$ 0.001)。さらに，最終全般改善度において「改善」 

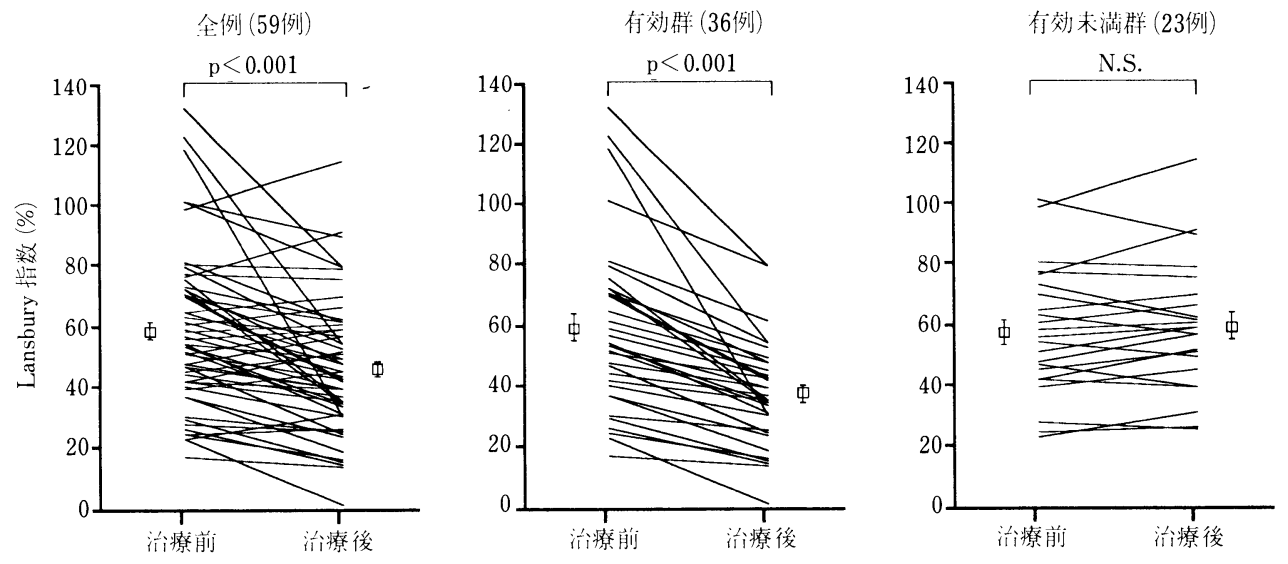

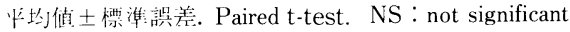

図 5 Lansbury 指数の経時変化

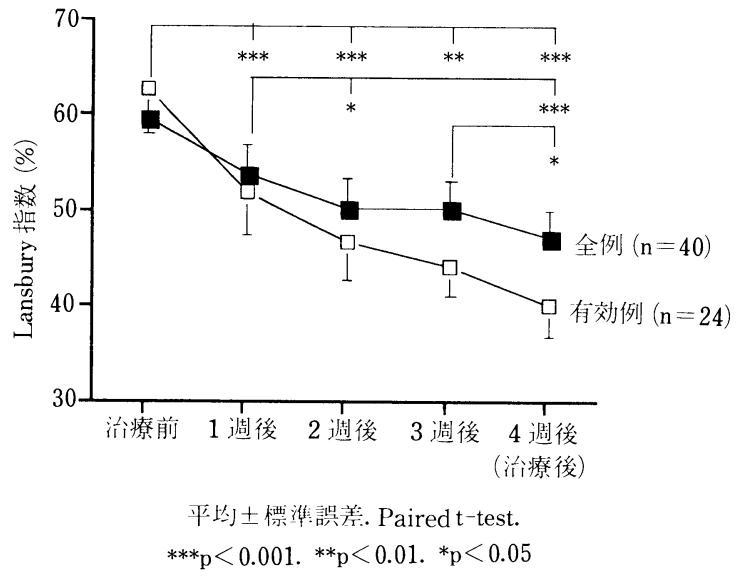

図 64 週間施行群の Lansbury 指数の経時変化

以上を「有効」,「改善」未満を「有効未満」とし， 有効群 (36 例) に打ける改善をみると, 治療終了後 では前值に対して $35.8 \%(60.9 \% \rightarrow 39.1 \%)$ と著 明に改善した $(\mathrm{p}<0.001$ ) (図 5 ).

なお，治療前は G-1 開始直前のデー夕を用い， 治療終了後としては G-1 終了直後から 2 週目ま でのデー夕を用いた。

また, 症例数の多かった 4 週間施行群 (40 例) に ついて, Lansbury 指数の経時的変化を検討した (図 6 ).

Lansbury 指数は G-1 治療開始 1 週後で有意 $(\mathrm{p}<0.001)$ に改善し, 1 週後と 2 週後, 1 週後と 4 週後, また, 3 週後と 4 週後の間でも改善率に 有意な差を認めた。したがって，G-1は 1 週間の
施行で Lansbury 指数の改善に効果が得られる が，4 週連続治療を重ねることにおいて，より顕 著な改善が得られることが示された。

(2) Lansbury 指数の各因子の検討

Lansbury 指数の各因子の変化を図 $7 \mathrm{a} \cdot \mathrm{b}$ 打 よび表 8 に示した. 表 8 の関節点数の減少, 不変, 増加は治療前後において点数の減少，増加を認め た症例は減少, 増加とし, まったく変化のなかっ た症例は「不変」とした。朝のこわばり, 握力, 赤沈については, $\pm 10 \%$ を不変領域として評価し た.

その結果, 赤沈を除く Lansbury 指数の各因子 は全例において有意な改善を示した。特に疼痛関 節点数, 腫脹関節点数, 活動性関節点数は有効群 および有効未満群の両群とも, G-1 後有意に低下 L, G-1 療法の特徵と考えられた，疼痛関節点数 については有効例の $100 \%$ に減少が認められ，全 症例 59 例中 16 例に疼痛関節点数の消失が認めら れた。また，赤沈については有意な改善は得られ なかったが, 有効群では平均值が約 $64 \mathrm{~mm} / 1$ 時 間から $58 \mathrm{~mm} / 1$ 時間に低下した。

（3）その他の有効性評価項目の検討

日常生活動作 ( $\mathrm{ADL})$, 顆粒球数, および CRP に ついて G-1 前後の変化を検討した.

$\mathrm{ADL}$, 顆粒球数の G-1 前後の変化を図 8 およ び表 9 に示した.リウマチ日記から評価した $\mathrm{ADL}$ は 59 例中 34 例 (57.6\%)に改善が認めら れ, 全症例および有効群において, 治療前と比較 


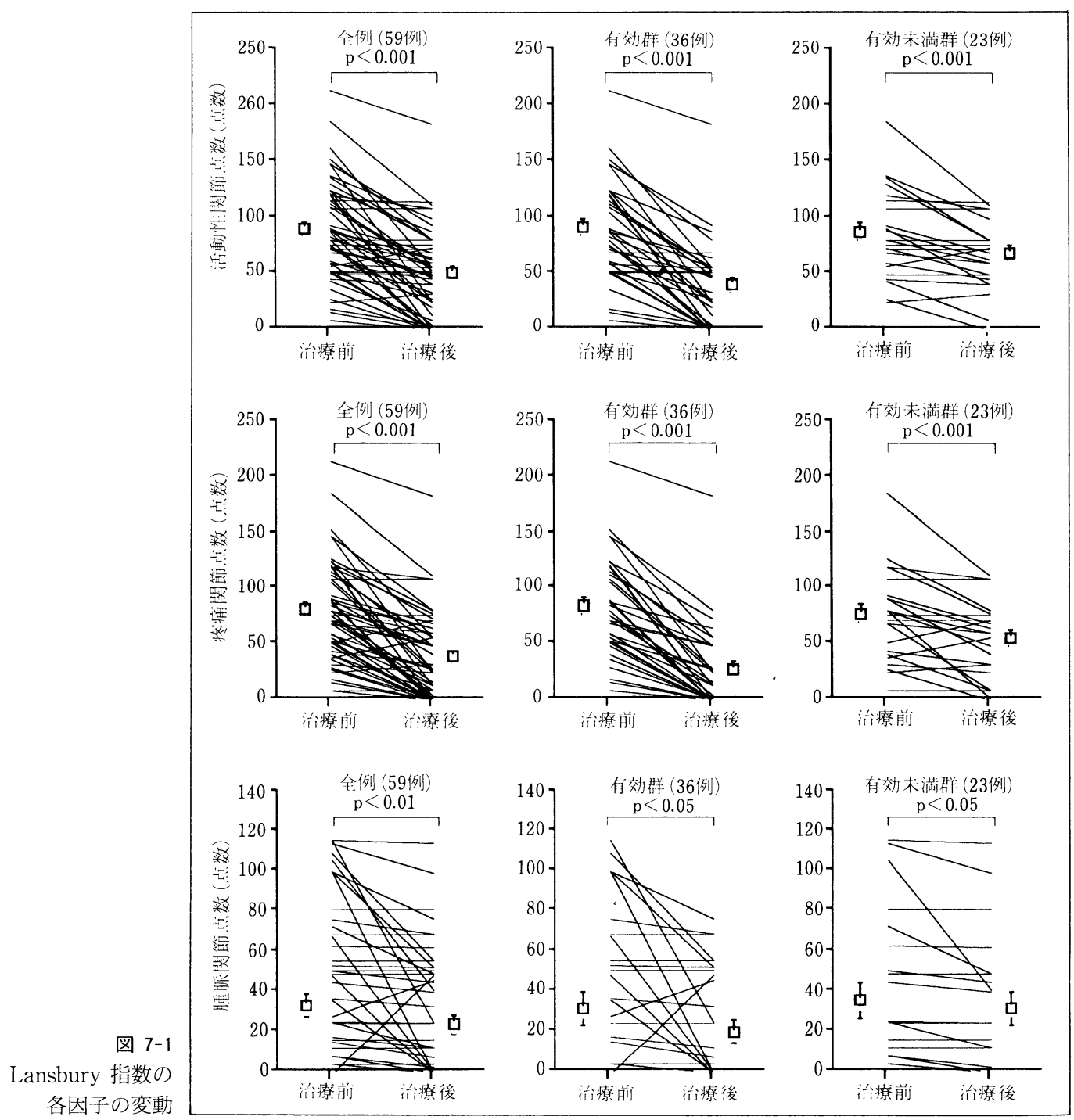

して治療終了後では有意に $(\mathrm{p}<0.001)$ 低下した. このことより G-1 は，RA 患者の QOL を改善す ることが示唆された。

顆粒球数についても同様の結果であった。すな わち，有効群では治療終了後有意に低下し， G-1 による RA 症状の改善とともに末梢血中から炎 症性細胞が減少することが示された。

$\mathrm{RF}$ については, 59 例中 21 例, CRP について は 22 例の患者が， G-1 治療前にくらべ $10 \%$ 以上 低下した。なお， G-1 前と比較して $10 \%$ 以上の低 下を「低下」，10\%以上の上昇を「上昇」，その間 を「不変」として表 10 に示した。

\section{総合評価}

有効性評価症例 59 例について, 本治験の有効性 に関する最終全般改善度 (Lansbury 指数を指標 とした), 安全性に関する概括安全度および最終全 般改善度と概括安全度を総合的に評価した有用度 の結果を表 11〜表 13 に示した.

その結果, 最終全般改善度は「改善」以上 $61.0 \%$ (36/59)，「やや改善」以上 $74.6 \%(44 / 59)$ ，概括安 全度は「安全である」98.4\% (62/63)であり，有用 度は「有用」以上 $61.0 \%(36 / 59)$,「やや有用」以 上 $76.3 \%(45 / 59)$ と $\mathrm{G}-1$ は RA 患者の治療の一 環としてすぐれた有用性を示した。 

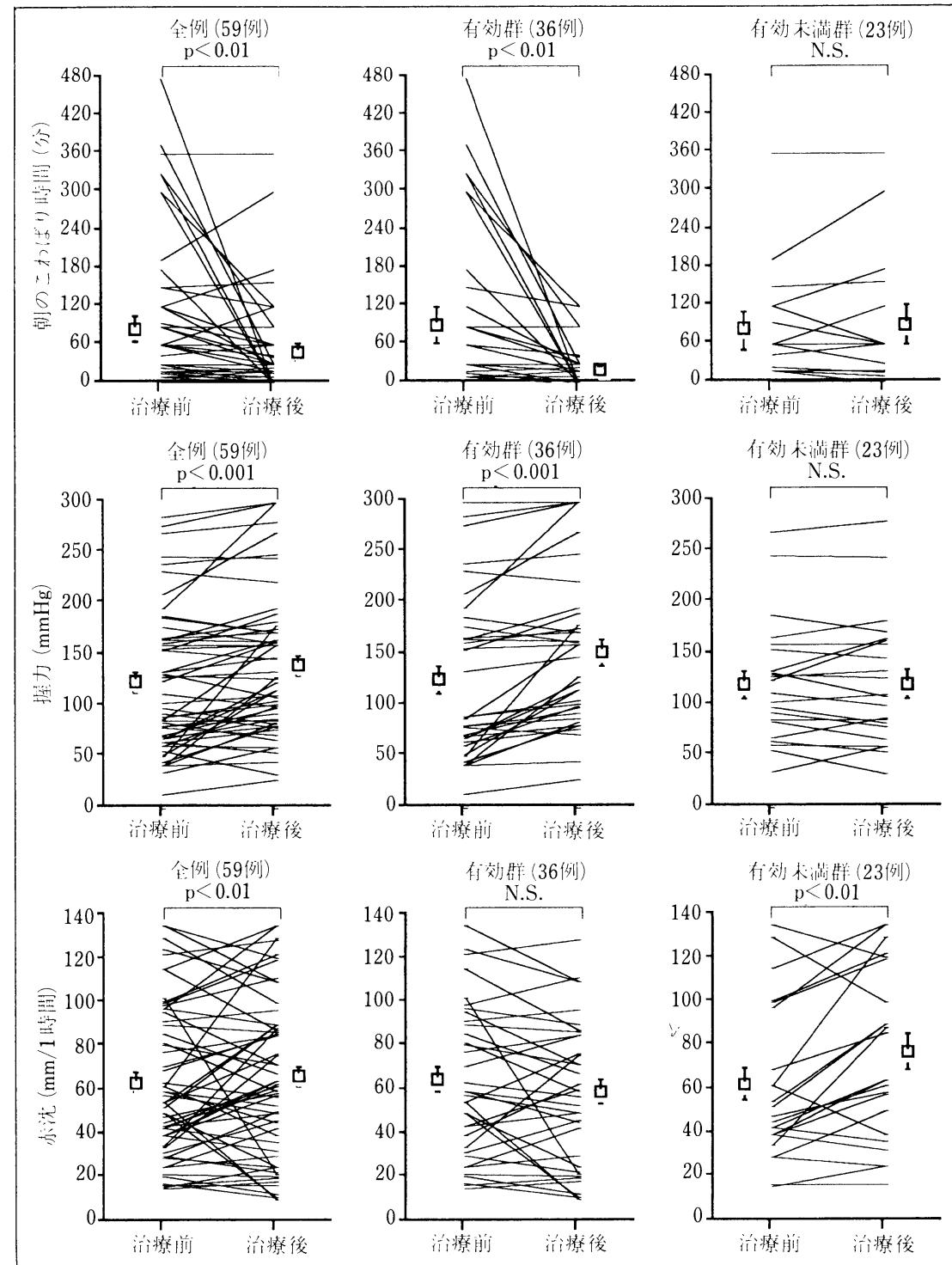

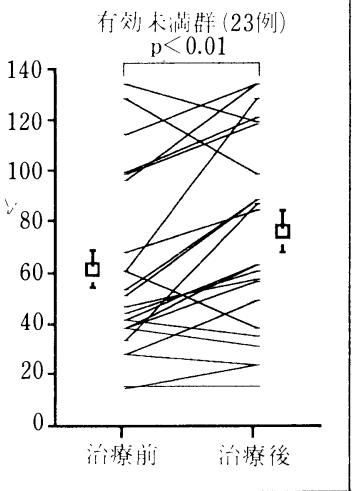

図 7-2

Lansbury 指数の 各因子の変動

\section{施設別最終全般改善度}

グループ間の最終全般改善度に有意差はなかっ た ( $\chi^{2}$ 検定) (表 14).

\section{効果別背景および各評価項目の初期値}

有効性評価症例 59 例について, 最終全般改善度 において「改善」以上を「有効」，「改善」未満を 「有効未満」とし，2 群間の背景および各評価項目 の初期值を比較検討した。

患者背景については，有効群に罹病期間のなが い症例が多かったことを除いて, 有効群：有効未
満群に差はなかった(表 15)。

各評価項目の初期值については両群間に有意差 はなかった(表 16).

\section{臨床検査}

臨床検査值 (一般血液検査, 血液生化学検査, 尿 検査)の異常については, アミロイド腎合併による 腎機能障害があった 1 例(症例 No. 001) に一時的 な障害の増強が認められた。この障害の増強は G-1 終了 4 週後に前值に戻った。また，症例 No. 016 では GPT 值が 156 IU/1 に増加したが，これ 
表 8 Lansbury 指数の各因子の改善度

\begin{tabular}{|c|c|c|c|c|c|c|c|c|}
\hline \multirow{2}{*}{ 項目 } & & \multirow{2}{*}{ 全症例 } & \multirow{2}{*}{$(\%)$} & \multicolumn{5}{|c|}{ 最終全般改善度 } \\
\hline & & & & 有効群 & $(\%)$ & 有効末満群 & $(\%)$ & $\chi^{2}$ 検定 \\
\hline 症例数 & & 59 & & 36 & & 23 & & \\
\hline \multirow{3}{*}{$\begin{array}{l}\text { 活動性関節 } \\
\text { 点数 }\end{array}$} & 減少 & 50 & 84.7 & 34 & 94.4 & 16 & 69.6 & \multirow{3}{*}{$\mathrm{p}<0.001$} \\
\hline & 不変 & 7 & 11.9 & 2 & 5.6 & 5 & 21.7 & \\
\hline & 增加 & 2 & 3.4 & () & 0.0 & 2 & 8.7 & \\
\hline \multirow{3}{*}{$\begin{array}{l}\text { 疼痛関節 } \\
\text { 点数 }\end{array}$} & 減少 & 52 & 88.1 & 36 & 100.0 & 16 & 69.6 & \multirow{3}{*}{$\mathrm{p}<0.001$} \\
\hline & 不変 & 4 & 6.8 & 0 & 0.0 & 4 & 17.4 & \\
\hline & 増加 & 3 & 5.1 & 0 & 0.0 & 3 & 13.0 & \\
\hline \multirow{3}{*}{$\begin{array}{l}\text { 腫脹関節 } \\
\text { 点数 }\end{array}$} & 減少 & 26 & 44.1 & 14 & 41.7 & 12 & $\overline{5} 2.2$ & \multirow{3}{*}{ NS } \\
\hline & 不変 & 31 & 52.5 & 20 & 52.8 & 11 & 43.5 & \\
\hline & 増加 & 2 & 3.4 & 2 & 5.6 & 0 & 4.3 & \\
\hline \multirow{3}{*}{$\begin{array}{l}\text { 朝の } \\
\text { こわばり }\end{array}$} & 減少 & 24 & 40.7 & 18 & 50.0 & 6 & 26.1 & \multirow{3}{*}{ NS } \\
\hline & 不変 & 29 & 49.2 & 16 & 44.4 & 13 & 56.5 & \\
\hline & 増加 & 6 & 10.2 & 2 & 5.6 & 4 & 17.4 & \\
\hline \multirow{3}{*}{ 握力 } & 増加 & 25 & 42.4 & 20 & 55.6 & 5 & 21.7 & \multirow{3}{*}{$\mathrm{p}<0.001$} \\
\hline & 不変 & 27 & 45.8 & 16 & 44.4 & 11 & 47.8 & \\
\hline & 減少 & 7 & 11.9 & () & 0.0 & 7 & 30.4 & \\
\hline \multirow{3}{*}{ 赤沈 } & 低下 & 24 & 40.7 & 18 & 50.0 & 6 & 26.1 & \multirow{3}{*}{$\mathrm{p}<0.05$} \\
\hline & 不変 & 7 & 11.9 & 6 & 16.7 & 1 & 4.3 & \\
\hline & 上舁 & 28 & 47.5 & 12 & 33.3 & 16 & 69.6 & \\
\hline
\end{tabular}
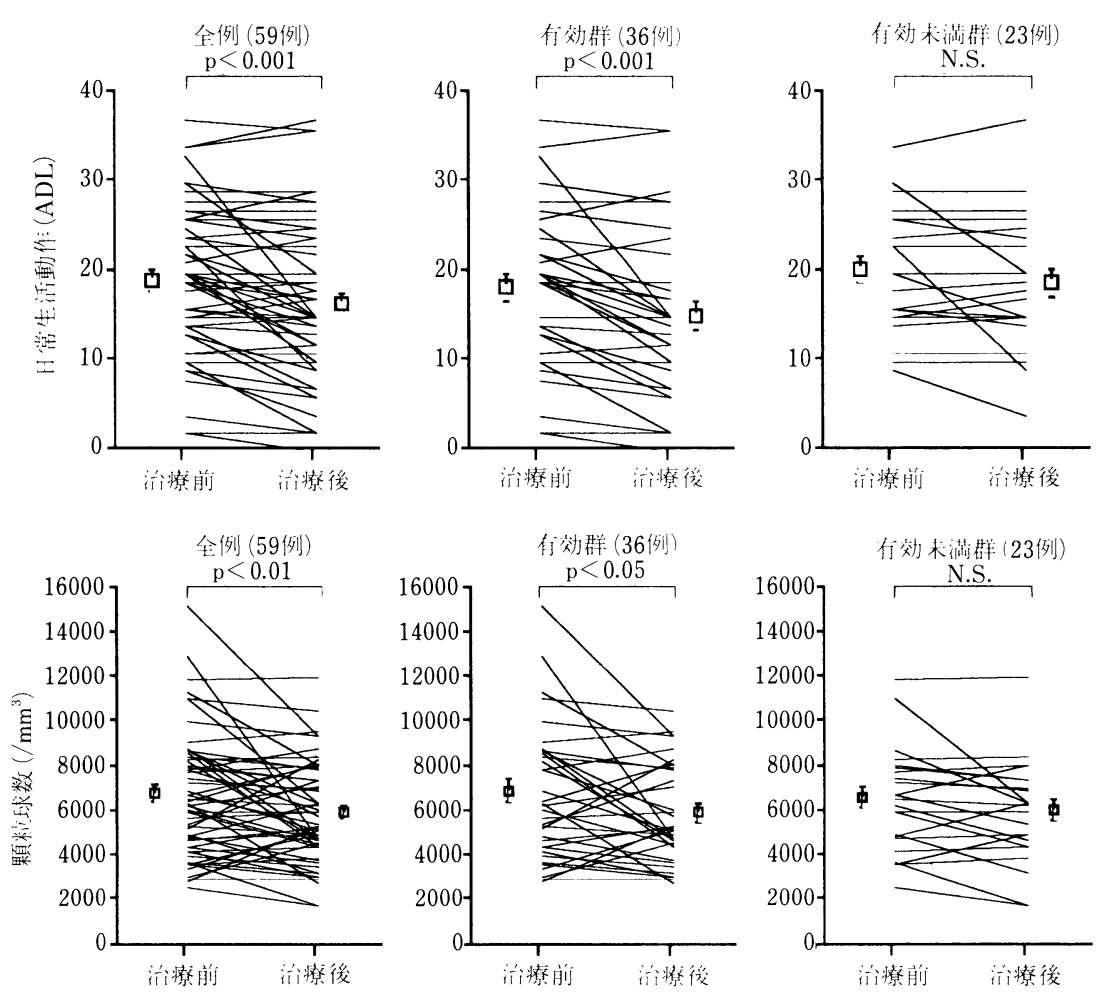
表 9 日常生活動作 (ADL)の改善度

\begin{tabular}{|c|c|c|c|c|c|c|c|c|}
\hline \multirow{2}{*}{ 項目 } & & \multirow{2}{*}{ 全症例 } & \multirow{2}{*}{$(\%)$} & \multicolumn{5}{|c|}{ 最終全般改善度 } \\
\hline & & & & 有効群 & $(\%)$ & 有効末満群 & $(\%)$ & $\chi^{2}$ 検定 \\
\hline \multirow{3}{*}{$\begin{array}{c}\text { 日常生活動作 } \\
\text { (ADL) }\end{array}$} & 改善 & 34 & 57.6 & 24 & 66.7 & 10 & 43.5 & \multirow{3}{*}{ NS } \\
\hline & 不変 & 15 & 25.4 & 8 & 22.2 & 7 & 30.4 & \\
\hline & 悪化 & 10 & 16.9 & 4 & 11.1 & 6 & 26.1 & \\
\hline
\end{tabular}

表 10 RF, CRP の変動

\begin{tabular}{cc|c|c|c|c|c}
\hline & & 症例数 & 低下 & 不変 & 上昇 & 低下率 \\
\hline $\mathrm{RF}$ & $(\mathrm{U} / \mathrm{ml})$ & 59 & 21 & 14 & 24 & $35.6 \%$ \\
\hline $\mathrm{CRP}$ & $(\mathrm{mg} / \mathrm{dl})$ & 59 & 22 & 9 & 28 & $37.3 \%$ \\
\hline
\end{tabular}

表 11 最終全般改善度の評価

\begin{tabular}{|c|c|c|c|c|c|c|c|c|c|}
\hline \multirow{2}{*}{ 例数 } & \multicolumn{7}{|c|}{ 評価 } & \multirow{2}{*}{$\begin{array}{c}\text { 「改善」 } \\
\text { 以上 }\end{array}$} & \multirow{2}{*}{$\begin{array}{c}\text { 「や改善] } \\
\text { 以上 }\end{array}$} \\
\hline & 著明改善 & 改善 & やや改善 & 不変 & やや悪化 & 悪化 & 著明悪化 & & \\
\hline 59 & 22 & 14 & 8 & 13 & 2 & 0 & 0 & $\begin{array}{c}36 \\
(61.0 \%)\end{array}$ & $\begin{array}{c}44 \\
(74.6 \%)\end{array}$ \\
\hline
\end{tabular}

表 12 概括安全度の評価

\begin{tabular}{c|c|c|c|c}
\hline \multirow{2}{*}{ 例数 } & \multicolumn{4}{|c}{ 評価 } \\
\cline { 2 - 5 } & $\begin{array}{c}\text { 安全で } \\
\text { ある }\end{array}$ & $\begin{array}{c}\text { ほぼ安全 } \\
\text { である }\end{array}$ & $\begin{array}{c}\text { 安全性に } \\
\text { 問題がある }\end{array}$ & $\begin{array}{c}\text { 安全で } \\
\text { ない }\end{array}$ \\
\hline 63 & $\begin{array}{c}62 \\
(98.4 \%)\end{array}$ & 1 & 0 & 0 \\
\hline
\end{tabular}

表 13 有用度の評価

\begin{tabular}{|c|c|c|c|c|c|c|c|c|c|}
\hline \multirow[b]{2}{*}{ 例数 } & \multicolumn{7}{|c|}{ 評価 } & \multirow{2}{*}{$\begin{array}{c}{[\text { 有用」 }} \\
\text { 以上 }\end{array}$} & \multirow{2}{*}{$\begin{array}{c}\text { やや有用 }] \\
\text { 以上 }\end{array}$} \\
\hline & $\begin{array}{c}\text { 極めて } \\
\text { 有用 }\end{array}$ & 有用 & $\begin{array}{l}\text { やや } \\
\text { 有用 }\end{array}$ & $\begin{array}{l}\text { ぞちらとも } \\
\text { いえない }\end{array}$ & $\begin{array}{l}\text { やや好ま } \\
\text { しくない }\end{array}$ & $\begin{array}{c}\text { 好ましく } \\
\text { ない }\end{array}$ & $\begin{array}{c}\text { 極めて好ま } \\
\text { しくない }\end{array}$ & & \\
\hline 59 & 21 & 15 & 9 & 13 & 1 & 0 & 0 & $\begin{array}{c}36 \\
(61.0 \%)\end{array}$ & $\begin{array}{c}45 \\
(76.3 \%)\end{array}$ \\
\hline
\end{tabular}

表 14 施設別効果

\begin{tabular}{|c|c|c|c|c|c|c|c|c|c|c|}
\hline グループ & 症例数 & 著明改善 & 改善 & やや改善 & 不変 & やや悪化 & 悪化 & 著明悪化 & $\begin{array}{c}\text { [改善」以上 } \\
(\%)\end{array}$ & $\begin{array}{c}\Gamma \text { や改善」以上 } \\
(\%)\end{array}$ \\
\hline A & 33 & 15 & 6 & 3 & 8 & 1 & 0 & 0 & $\begin{array}{c}21 \\
63.6 \%\end{array}$ & $\begin{array}{c}24 \\
72.7 \%\end{array}$ \\
\hline B & 26 & 7 & 8 & 5 & 5 & 1 & 0 & 0 & $\begin{array}{c}15 \\
57.7 \%\end{array}$ & $\begin{array}{c}20 \\
76.9 \%\end{array}$ \\
\hline 計 & 59 & 22 & 14 & 8 & 13 & 2 & 0 & 0 & $\begin{array}{l}36 \\
61.0 \%\end{array}$ & $\begin{array}{c}44 \\
74.6 \%\end{array}$ \\
\hline
\end{tabular}




\begin{tabular}{|c|c|c|c|c|c|c|c|c|c|}
\hline $\begin{array}{l}\text { 症例 } \\
\text { No. }\end{array}$ & 検查項目 & $\begin{array}{l}\mathrm{G}-1 \\
\text { 開始 } \\
5 \text { 週前 }\end{array}$ & $\begin{array}{c}G-1 \\
\text { 開始時 }\end{array}$ & $\begin{array}{l}\mathrm{G}-1 \\
\text { 終了 } \\
1 \text { 週後 }\end{array}$ & $\begin{array}{l}\mathrm{G}-1 \\
\text { 終了 } \\
3 \text { 週後 }\end{array}$ & $\begin{array}{l}\text { G-1 } \\
\text { 終了 } \\
4 \text { 週後 }\end{array}$ & $\begin{array}{l}\text { 併用薬 } \\
\text { 中止 } \\
2 \text { 日後 }\end{array}$ & $\begin{array}{l}\text { 併用薬 } \\
\text { 中止 } \\
6 \text { 週後 }\end{array}$ & 担当医師コメント \\
\hline 001 & $\begin{array}{l}\mathrm{BUN}(\mathrm{mg} / \mathrm{dl}) \\
\text { クレアチニン } \\
\quad(\mathrm{mg} / \mathrm{dl})\end{array}$ & & $\begin{array}{l}41 \\
2.4\end{array}$ & $\begin{array}{l}74 \\
3.5\end{array}$ & $\begin{array}{l}72 \\
3.7\end{array}$ & $\begin{array}{l}49 \\
2.3\end{array}$ & & & $\begin{array}{l}\mathrm{BUN}, \text { クレアチニンの上昇は } \mathrm{G}-1 \\
\text { 終了 } 3 \text { 週までは認められたが, } 4 \\
\text { 週後には前值に戻った. }\end{array}$ \\
\hline 016 & $\begin{array}{ll}\text { GPT } & (\mathrm{IU} / 1) \\
\gamma \text {-GTP } & (\mathrm{IU} / \mathrm{l}) \\
\text { ALP } & (\mathrm{IU} / 1)\end{array}$ & $\begin{array}{r}37 \\
155 \\
545\end{array}$ & $\begin{array}{r}32 \\
165 \\
547\end{array}$ & $\begin{array}{r}85 \\
265 \\
679 \\
\text { 5ゾス }\end{array}$ & $\begin{array}{l}156 \\
306 \\
812 \\
\uparrow \\
\text { ファピリ }\end{array}$ & 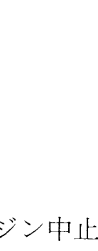 & $\begin{array}{l}104 \\
277 \\
740\end{array}$ & $\begin{array}{r}16 \\
91 \\
290\end{array}$ & $\begin{array}{l}\text { 本治療開始前から GPT, } \gamma-G T P, \\
\text { ALPが異常儿進しており, 治療終 } \\
\text { 了 } 3 \text { 週後のサラゾスルファヒヒリ゙ } \\
\text { ン中止により, 速やかに減少し, } \\
\text { サラゾスルファピリジン中止 } 6 \text { 週 } \\
\text { 後には正常値付近まで戻っている } \\
\text { ため, 本治療との因果関係はない } \\
\text { ものと考ええるる. }\end{array}$ \\
\hline
\end{tabular}

臨床検査値

表 15 効果別背景

\begin{tabular}{|c|c|c|c|c|c|}
\hline \multicolumn{3}{|c|}{ 背景因子 } & \multicolumn{3}{|c|}{ 有効評価症例 (59 例) } \\
\hline 項目 & 区分 & & $\begin{array}{l}\text { 有効 } \\
\text { (36 例) }\end{array}$ & $\begin{array}{l}\text { 有効末満 } \\
(23 \text { 例 })\end{array}$ & $\chi^{2}$ 検定 \\
\hline 性別 & $\begin{array}{l}\text { 男 } \\
\text { 女 }\end{array}$ & & $\begin{array}{r}6 \\
30\end{array}$ & $\begin{array}{r}5 \\
18\end{array}$ & NS \\
\hline 年歯 & $\begin{aligned} & \sim 49 \\
& \sim 59 \\
& \sim 69 \\
& 70 \sim\end{aligned}$ & & $\begin{array}{r}4 \\
17 \\
11 \\
4\end{array}$ & $\begin{array}{r}2 \\
10 \\
10 \\
1\end{array}$ & NS \\
\hline $\begin{array}{l}\text { 入院 } \\
\text { 外来 }\end{array}$ & $\begin{array}{l}\text { 入院 } \\
\text { 外来 }\end{array}$ & & $\begin{array}{l}26 \\
10\end{array}$ & $\begin{array}{l}13 \\
10\end{array}$ & NS \\
\hline $\begin{array}{l}\text { 病期 } \\
\text { (stage) }\end{array}$ & $\begin{array}{l}\text { I } \\
\text { II } \\
\text { III } \\
\text { IV }\end{array}$ & & $\begin{array}{r}6 \\
5 \\
8 \\
17\end{array}$ & $\begin{array}{r}0 \\
7 \\
6 \\
10\end{array}$ & NS \\
\hline $\begin{array}{l}\text { 機能 } \\
\text { 障害度 } \\
\text { (class) }\end{array}$ & $\begin{array}{l}1 \\
2 \\
3 \\
4\end{array}$ & & $\begin{array}{r}7 \\
21 \\
6 \\
2\end{array}$ & $\begin{array}{r}1 \\
16 \\
6 \\
0\end{array}$ & NS \\
\hline $\begin{array}{l}\text { 罹病 } \\
\text { 期間 }\end{array}$ & $\begin{array}{r}\sim 3 \text { 年未満 } \\
\sim 7 \text { 年末満 } \\
\sim 12 \text { 年末満 } \\
12 \text { 年以上 }\end{array}$ & & $\begin{array}{r}5 \\
14 \\
2 \\
15\end{array}$ & $\begin{array}{l}5 \\
4 \\
7 \\
7\end{array}$ & $\mathrm{p}<0.05$ \\
\hline & ステロイド剤 & + & $\begin{array}{l}24 \\
12\end{array}$ & $\begin{array}{r}15 \\
8\end{array}$ & NS \\
\hline 併用 & 免疫抑制剤 & + & $\begin{array}{l}12 \\
24\end{array}$ & $\begin{array}{l}12 \\
11\end{array}$ & NS \\
\hline 楽威 & $\begin{array}{l}\text { 金斉・D-Pc など } \\
\text { (抗リウマチ褕) }\end{array}$ & $\begin{array}{l}+ \\
-\end{array}$ & $\begin{array}{l}18 \\
18\end{array}$ & $\begin{array}{l}13 \\
10\end{array}$ & NS \\
\hline & 非ステロイド剤 & $\begin{array}{l}+ \\
-\end{array}$ & $\begin{array}{r}35 \\
1\end{array}$ & $\begin{array}{r}23 \\
0\end{array}$ & NS \\
\hline
\end{tabular}

は併用したサラゾスルファピリジンによるものと 考えられ, 併用薬中止 6 週後に GPT 值は $16 \mathrm{IU} /$ 1 と正常值に戻った。

\section{副作用}

副作用の評価対象症例 63 例において，G-1 を 行った延べ回数は 437 回であった。このうち副作 用発現の報告については, G-1 施行後, 約半日程 度頭痛が出現した症例が 1 例あったが，この症状 は経過観察だけで消失した。

\section{考 案}

本試験は，G-1 を用いて体外循環法により末梢 血中の顆粒球を体外吸着し, 慢性関節リウマチ (RA) に対する有効性，安全性，有用性，および用 法・用量を検討する目的で実施された。

RA は原因不明の疾患であるが， RA 患者の滑 液内細胞は顆粒球が $98 \%$ を占めており，関節破壊 の主な原因としては，顆粒球の産生する蛋白分解 酵素や活性酵素が考えられる。

今回の試験で，末梢血中の顆粒球を体外吸着す ることにより，治療後には末梢血顆粒球数が有意 $(\mathrm{p}<0.01)$ に減少した。また, 疼痛関節点数, 腫 脹関節点数など関節症状が治療前後で有意 $(\mathrm{p}<$ $0.001, \mathrm{p}<0.01)$ に改善したことから, 滑液内の顆 粒球が本治療により鎮静化することが推察され た。

RA に対する臨床試験で有効性を明確に評価で 
表 16 効果別各評価項目の初期值

\begin{tabular}{|c|c|c|c|c|c|}
\hline \multirow{2}{*}{\multicolumn{3}{|c|}{ 項目 }} & \multicolumn{2}{|c|}{$\begin{array}{c}\text { 有効性評価症例 (59 例) } \\
\text { 平均值 }(\text { mean } \pm \mathrm{SE})\end{array}$} & \multirow{2}{*}{$\mathrm{t}$ 検定 } \\
\hline & & & 有効群 (36 例) & 有効末満群 (23 例) & \\
\hline \multicolumn{2}{|c|}{ 朝のこわばり } & (分) & $87.5 \pm 21.8$ & $81.7 \pm 25.2$ & NS \\
\hline \multicolumn{2}{|c|}{ 握力 } & $(\mathrm{mmHg})$ & $122.3 \pm 13.4$ & $117.2 \pm 13.2$ & NS \\
\hline \multicolumn{2}{|c|}{ 赤沈 } & $(\mathrm{mm} / \mathrm{hr})$ & $62.7 \pm 5.7$ & $61.2 \pm 7.3$ & NS \\
\hline \multirow{6}{*}{$\begin{array}{l}\text { 活 } \\
\text { 動 } \\
\text { 性 } \\
\text { 関 } \\
\text { 節 } \\
\text { 数 }\end{array}$} & \multicolumn{2}{|l|}{ 疼痛関節数 } & $8.4 \pm 1.2$ & $9.5 \pm 1.8$ & NS \\
\hline & \multicolumn{2}{|c|}{ 疼痛関節点数 } & $82.0 \pm 7.5$ & $75.0 \pm 8.5$ & $\mathrm{NS}$ \\
\hline & \multicolumn{2}{|l|}{ 腫脹関節数 } & $5.1 \pm 1.1$ & $7.8 \pm 1.9$ & $\mathrm{NS}$ \\
\hline & \multicolumn{2}{|c|}{ 腫脹関節点数 } & $30.3 \pm 6.5$ & $34.6 \pm 8.3$ & NS \\
\hline & \multicolumn{2}{|c|}{ 活動性関節数 } & $11.4 \pm 1.4$ & $14.3 \pm 2.1$ & NS \\
\hline & \multicolumn{2}{|c|}{ 活動性関節点数 } & $89.1 \pm 7.5$ & $85.4 \pm 8.2$ & NS \\
\hline \multicolumn{2}{|c|}{ Lansbury 指数 } & $(\%)$ & $60.9 \pm 4.6$ & $59.0 \pm 4.4$ & NS \\
\hline \multicolumn{2}{|c|}{ 日常生活動作 } & (ADL score) & $18.0 \pm 1.6$ & $19.9 \pm 1.4$ & NS \\
\hline \multicolumn{2}{|c|}{$\mathrm{RF}$} & $(\mathrm{U} / \mathrm{ml})$ & $235.4 \pm 58.2$ & $193.7 \pm 35.9$ & NS \\
\hline \multicolumn{2}{|c|}{ CRP } & $(\mathrm{mg} / \mathrm{dl})$ & $4.3 \pm 0.65$ & $4.9 \pm 0.75$ & NS \\
\hline \multicolumn{2}{|c|}{ 顆粒球数 } & $\left(\times 10^{3} / \mathrm{mm}^{3}\right)$ & $6.87 \pm 0.50$ & $6.50 \pm 0.50$ & NS \\
\hline \multicolumn{2}{|c|}{ リンパ球数 } & $\left(\times 10^{3} / \mathrm{mm}^{3}\right)$ & $1.36 \pm 0.11$ & $1.46 \pm 0.11$ & NS \\
\hline \multicolumn{2}{|c|}{ 単球数 } & $\left(\times 10^{3} / \mathrm{mm}^{3}\right)$ & $0.40 \pm 0.03$ & $0.42 \pm 0.04$ & $\mathrm{NS}$ \\
\hline
\end{tabular}

きる臨床検査法はいまのところない。そこで，今 回の試験では RA の活動性を示す Lansbury 指数 を中心に評価した。その結果, 有効性評価対象例 59 例中, 著明改善 22 例, 改善 14 例, やや改善 8 例, 不変 13 例, やや悪化 2 例と著明改善の例数が もっとも多く良好な結果であった.

RA 患者で高值となるリウマトイド因子の改善 率は $35.6 \%$, CRP の改善率は $37.3 \%$ であった。 これらの結果は統計上有意ではないものの, 症例 No.002 においてはリウマトイド因子が $1227 \rightarrow$ $527 \mathrm{U} / \mathrm{ml}$ に減少するなど，顕著に減少する症例 もあった。

効果の発現時期としては, 抗りウマチ薬や免疫 抑制剂など, 長期投与で効果を示す薬剤が多いが, 本治療では 1 回の治療で効果が得られた症例も あった。しかし，治療を重ねることにより，より 高い改善効果が得られる症例もあり, 治療回数と しては 2 回 ( 1 週間)から 8 回 ( 4 週間)の間で臨床 症状により判断することがよいと考えられた。

本試験結果の特徵の一つとして, 関節症状の顕 著な改善, 特に疼痛関節点数の顕著な改善（59
例中 52 例， $88.1 \%$ 症例で改善) があげられ， これに伴う日常生活動作 $(\mathrm{ADL})$ の有意 $(\mathrm{p}<0.001)$ な改善があげられる。このことは，長期間の闘病 生活を余儀なくされる RA 患者の QOL 改善とい う点で非常に価值あることと考えられる。

副作用については, 総症例 63 例中 1 例で頭痛が みられたが, 経過観察中に消失した。臨床検查值 については, 症例 No. 016 でGPT, $\gamma$-GTP, ALP が上昇した。これはサラゾスルファピリジンの影 響と考えられ，併用薬の中止により減少した。

また, 症例 No.001 においては, BUN, クレア チニンが上昇したが，この上昇は一過性であり， 本治療との因果関係はないと考えられた，以上の ことから, 本治療はきわめて安全性の高い治療と 考えられた。

\section{まとめ}

本試験は，G-1 を用いた体外循環法による末梢 血中顆粒球の体外吸着療法につき，慢性関節りウ 
マチ (RA)に対する有効性, 安全性, 有用性, およ び用法・用量を検討する目的で実施された。活動 性 RA 患者を対象とし，4 施設で臨床試験を実施 し, 医療用具の性質上, オープン形式で検討した。

(1) 63 例の臨床試験成績より, G-1 に吸着する 白血球の約 $95 \%$ は単球を含む顆粒球であり，G-1 は顆粒球吸着特性の高い医療用具であることが示 された。

(2) 本治療により, 末梢血顆粒球数は有意 $(\mathrm{p}<$ 0.01) に減少した，このことから, 本治療が RA 患 者の炎症症状を低下させることができるものと考 えられた。

(3) 治験に参加した 63 例全例で安全性, 59 例 で有効性, 有用性を評価した。 RA 活動性の総合 指標である Lansbury 指数を指標とした最終全般 改善度は,「改善」以上 $61.0 \%$,「やや改善」以上 で 74.6\%と G-1 は RA 患者の治療の一環として 高い有効性を示した。 さらに, G-10顕著な効果 として疼痛関節点数が $88.1 \%$ の患者で軽減し, 悪 化したのは 3 例のみであった。このことは, 臨床 の場において, 多くの RA 患者の QOL 改善に寄 与することを期待させるものである.

(4) 副作用発現症例は 63 例中 1 例 (1.6\%)で, 因果関係を否定できない検査值異常を示した症例 は1例もなかった。したがって，G-1 はきわめて 安全性の高い医療用具であることが示された。

以上のことより，G-1 は，RA 患者の自他覚症 状の改善に効果を有し, 安全性の高い医療用具で あることが示された。

\section{文 献}

1) Romson, J. L., Hook, B. G., Kunkel, S. L., Abrams, G. D., Schork, M. A., Lucchecsi, B. R. : Reduction of the extent of ischemic myocardial injury by neutrophil depletion in the dog. Circulation 67:10161023, 1983.

2) Powe, J. E., Sibbald, W. J., Driedger, A. A. : Pulmonary accumulation of polymorphonuclear leukocytes in the adult respiratory distress syndrome. Crit. Care. Med. 10:712-718, 1982.

3) Deitch E. A. : Multiple organ failure : Pathophysiology and potential future therapy. Ann Surg. 216: 117-134, 1992.

4) Elford, P. R., Cooper P. H. : Induction of neutrophil- mediated cartilage degradation by interleukin-8. Arthritis Rheum. 34 : 325-332, 1991.

5) Schrier, D., Gilbertsen, R. B., Fantone, J. : The role of neutrophils in type II collagen-induced arthritis in rats. Am. J. Pathol. 117 : 26-29, 1984.

6) Baud, L., Nivez, M. P., Chansel, D., Ardaillou, R. : Stimulation by oxygen radicals of prostaglandin production by rat renal glomeruli. Kidney Int. 20 : 332-339, 1981.

7) Mohr, W., Westerhellweg, H., Wessinghage D. : Polymorphonuclear granulocytes in rheumatic tissue destruction. III. An electron microscopic study of PMNs at the pannus-cartilage junction in rheumatoid arthritis. Ann. Rheum. Dis. 40 : 396-399, 1981.

8) Mohr, W., Pelster, B., Wessinghage, D. : Polymorphonuclear granulocytes in rheumatic tissue destruction. IV. The occurrence of PMNs in menisci of patients with rheumatoid arthritis. Rheumatol. Int. $5: 39-44,1984$.

9) Ugai, K., Ishikawa, H., Hirohata, K., Shirane, H. : Interaction of polymorphonuclear leukocytes with immune complexes trapped in rheumatoid articular cartilage. Arthritis Rheum. $26: 1434-1441,1983$.

10) Vhelvart, M., Fehr, K.: Degradation in vivo of articular cartilage in rheumatoid arthritis and juvenile chronic arthritis by cathepsin $G$ and elastase from polymorphonuclear leukocytes. Rheumatol. Int. 7 : 195-202, 1987.

11) Jasin, H. E. : Autoantibody specificities of immune complexes sequestered in articular cartilage of patients with rheumatoid arthritis and osteoarthritis. Arthritis Rheum. 28 : 241-248, 1985.

12) Jasin, H. E., Taurog, J. D. : Mechanisms of disruption of the articular cartilage surface in inflammation. J. Clin. Invest. $87:$ 1531-1536, 1991.

13) Lloyd A. R., Oppenheim, J. J. : Poly's lament, The neglected role of the polymorphonuclear neutrophil in the afferent limb of the immune response. Immunol. Today $13: 169-172,1992$.

14) Bazzoni, F., Cassatella, M. A., Rossi, F., Ceska, M., Dewald, B., Baggiolini, M. : Phagocytosing neutrophils produce and release high amounts of the neutrophil-activating peptide/Interleukin 8. J. Exp. Med. 173: 771-774, 1991.

15) Dubravec, D. B., Spriggs, D. R., Mannick, J. A., Rodrick, M. L. : Circulating human peripheral blood granulocytes synthesize and secrete tumor necrosis factor. Proc. Natl. Acad. Sci. USA 87 : 6758-6761, 1990.

16) Elford, P. R., Cooper, P. M. : Induction of neutrophil-mediated cartilage degradation by Interleukin-8. Arthritis Rheum. 34 : 325-332, 1991. 